\title{
Effect of some mycotoxin on growth performance and feed utilization of Nile tilapia (Oreochromis niloticus)
}

\author{
F. I. Magouz ${ }^{1}$, M.S. Salem ${ }^{2}$ and M.A. Hashad ${ }^{2}$ \\ ${ }^{1}$ Department of Animal Production, Faculty of Agriculture, Kafrelsheikh University, Egypt \\ ${ }^{2}$ Central Laboratory for Aquaculture Research, Abbassa, Sharkia, Sakha Aquaculture Research Unit, Egypt
}

(Received November 25, 2017; Accepted January 7, 2018)

\begin{abstract}
The present study was conducted in the fish lab, Sakha Aquaculture Research Unit, Central laboratory for Aquaculture Research-Abbassa, during season 2015, Feeding experiment was conducted for 16 weeks to study the effect of dietary contamination with aflatoxin $\mathrm{B}_{1}\left(150 \mathrm{ppb}, \mathrm{AFB}_{1}\right)$ with and without the dietary supplementation of $(1 \mathrm{gm} / \mathrm{kg})$ of Liquorice (medicinal plants), (2g) of MTB-100 (chemicals) and (0.5g) of Gromin-plus (chemicals) on growth performance and feed utilization of Nile tilapia (Oreochromis niloticus) fingerlings. A group of 150 Nile Tilapia fingerlings (O. niloticus) with an average initial body weight $13.50 \mathrm{gm}$ were randomly allotted into 5 treatments in 10 glasses aquaria $(80 \times 35 \times 40 \mathrm{~cm})$. Each treatment was applied in two aquaria. Fresh tap water was stored in fiberglass tanks for $24 \mathrm{~h}$ under aeration for dechlorination. Prior to the start of the experiment, the fishes were adapted to a basal commercial diet (control diet) containing $31 \%$ crude protein and consisted of herring fish meal, soybean meal, yellow corn, wheat bran, sunflower oil and vitamins and minerals mixture for two weeks. These ingredients were pressed by manufactured machine (pellets size $1 \mathrm{~mm}$ ), milled and toxin AFB1 was added at a concentration of $150 \mathrm{ppb}$ except the control. Fish in all treatments were daily fed the experimental diets at level of $3 \%$ of the fish biomass. The feed amount was given at two times daily, six days a week for 16 weeks. Fish were weighed weekly and the feed amounts were adjusted on the basis of the new weight. The aflatoxic dite has adversely affected the growth performance and survival rate, feed utilization and carcass composition in fish and residues of $\mathrm{AFB}_{1}$ in the whole body of fish and indices organs and blood biochemistry of the experimented fish. Dietary MTB-100, Liquorice and Gromin-plus inclusion alleviated aflatoxiccosis semptoms by fish, since it improved all the above tested parameters of aflatoxicated fish. Generally, obtained results in the present study indicated that the additives all the above could be used as detoxifying agents for aflatoxins.
\end{abstract}

Keywords: Nile tilapia, Liquorice, MTB-100, Gromin-plus, aflatoxin B1 Available online at http://www.vetmedmosul.org/ijvs

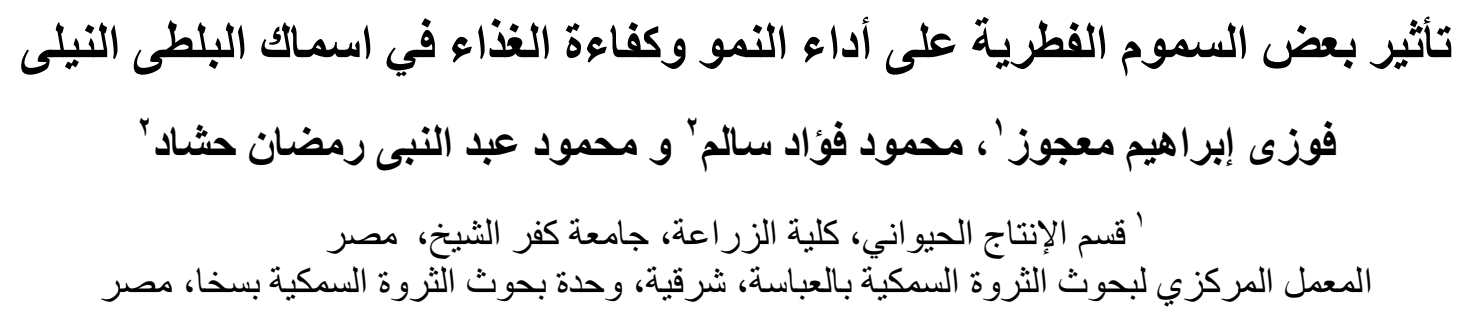

أجريت هذه الدر اسة بمعمل بحوث الاسماك، وحدة بحوث الثروة السمكية بسخا، المعمل المركزي لبحوث الثراث الثروة السمكية بالعباسة

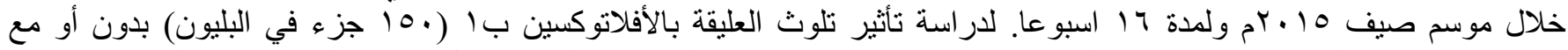

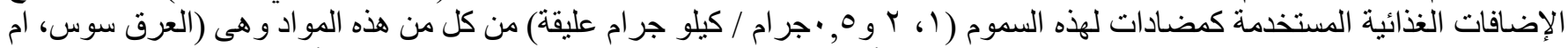

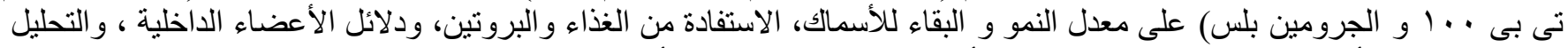

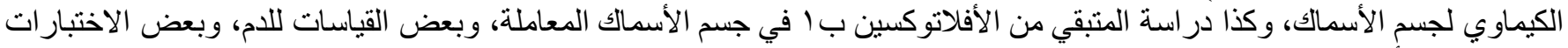

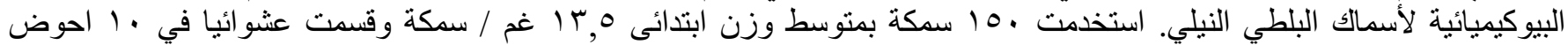




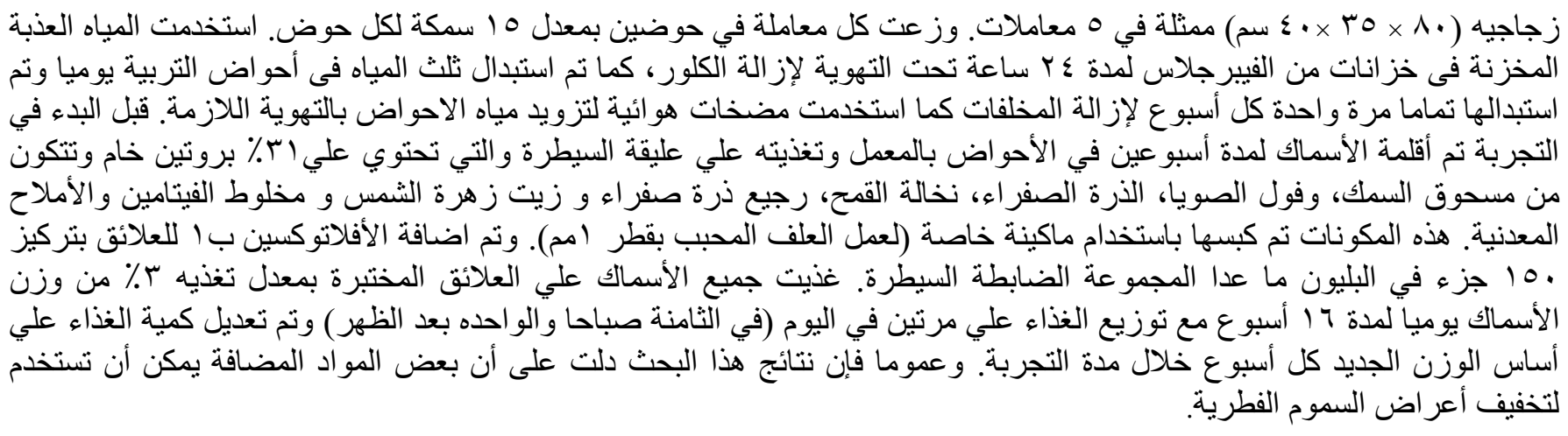

\section{Introduction}

Mycotoxins are highly toxic secondary products of the metabolism of some fungi mainly belonging to Aspergilus, penicillium, and Fusarium spp. Toxic syndromes caused by mycotoxin ingestion by humans and animals are indicated as mycotoxicosis (1). Since some mycotoxins (i.e., AFB1. FB1. OTA. and T2 toxin) are known to produce membrane damage through increased lipid peroxidation (2-6), the protective properties of antioxidant substances have been extensively investigated.

Many specialists are of the opinion that the best approach for decontamination should be degradation by biological matters giving a possibility for removal of $\mathrm{AF}$ under mild condition, without using harmful chemicals and without significant losses in nutritive value and palatability of detoxified feed and feedstuffs (7). Aflatoxins are considered the most carcinogenic, mutagenic and teratogenic poisonous by - product of the growth of the molds Aspergillus flavus and Aspergillus parasiticus, are the most studied and widely known mycotoxins. There are four major groups of aflatoxins: B1, B2, G1 and G2. Aflatoxins M1, a metabolite of aflatoxins B1 in mammals, may be found in the milk of animals eating feeds contaminated by Aflatoxins B1 (8-10). Practically, it is not possible to destroy the contaminated feed, therefore to prevent aflatoxicosis in fish by increasing animal immunity $(11,12)$ and detoxification chemically $(13)$ or biologically (14).

Aflatoxins are a major contaminant in aqua feeds and considered as a causative agent for fish mortality, morbidity and low productivity besides its residues in fish carcass leading to economic losses, human toxicity and affects public health especially in Egypt (15). A. flavus and $A$. parasiticus are abundant in the soil and are a common contaminant of feed crops in warm and humid environments $(1,16)$.

Tilapia grows and reproduces in a wide range of environmental conditions and tolerates stress induced by transmission (17). Currently, Egypt is one of the countries where, aquaculture is growing fast with Oreochromis niloticus, which is the most widely farmed species. Fisheries production in Egypt was recorded to be $1,481,882 /$ ton Year 2016 according to GAFRD (18).

Nile tilapia is still the most widely cultured species of tilapia in Africa. Nile tilapia is an economically important cultured species in several areas of the world $(19,20)$.

Nile tilapia is the most familiar and popular fishes in Egypt, as well as, in the Middle East and warm climate countries. Tilapia are widely cultured in the tropical, subtropical, and temperate regions of the world and represent the third largest productive group of farmed finfish species, only after carps and salmonids, with annual growth rate of about $12.2 \%$ (21).

Therefore, the present research aimed to study the drastic effect of AFB1 on growth performance and survival rate, feed utilization, body composition, indices organs, residues of the $\mathrm{AFB}_{1}$ in fish body and blood biochemistry as well as on the biochemical studies and histological examination of Nile tilapia (Oreochromis niloticus) fingerlings. Also, this study was conducted to evaluate the ability of some nutritional agents, namely Liquorice (as medicinal plants), MTB-100 (as chemicals) and Gromin-plus (as chemicals) at levels of 1,2 and $0.5 \mathrm{~g} / \mathrm{kg}$ feed from each to detoxify the drastic effects of this dangerous toxin AFB1 on Nile tilapia.

\section{Materials and methods}

\section{Experimental fish}

The experimental fish, (Oreochromis niloticus), were collected from a private farm in Tolombat 7 EL-Riyadh, Kafr EL-Sheikh governorate. The experimental started in October 2015 and lasted up to January 2016. The fingerlings were placed in a fiberglass tank and then randomly distributed into experimental aquaria for the acclimatization purpose on the experimental conditions until starting the diet. Fish were fed the diet for two weeks, during this period, healthy fish at the same weight replaced the dead fish. 


\section{Experimental design of rearing fish}

A group of 150 Nile Tilapia fingerlings (O. niloticus) fish with an average initial body weight $13.50 \mathrm{~g}$ were randomly allotted into 5 treatments in 10 glasses aquaria $(80 \times 35 \times 40 \mathrm{~cm})$. Each treatment was applied in two aquaria. Fresh tap water was stored in fiberglass tanks for $24 \mathrm{~h}$ under aeration for dechlorination. One third of the water in each aquarium was replaced daily and totally once every week after removing the wastes. Ten air stones were used for aerating the aquaria. Water temperature ranged between 25 and $28{ }^{\circ} \mathrm{C}$. Photoperiod was adjusted to be $14 \mathrm{~h}$ light and $10 \mathrm{~h}$ darkness using florescent light. Fish feces and feed residue were removed daily by siphoning.

\section{Experimental diets and regime}

Before the beginning of the experimental trail about two weeks the fishes were adapted for about two weeks on the basal diet containing $31 \%$ crude protein. A basal diet was formulated from the commercial ingredients (herring meal, soybean meal, yellow corn, wheat bran, sunflower oil and Vit. \& Min mixture). These ingredients were pressed by manufactured machine (pellets size $1 \mathrm{~mm}$ ), milled and toxin AFB1 was added at a concentration of $150 \mathrm{ppb}$ except the control. Anti-mycotoxin was added at a concentration of $1 \mathrm{~g}$ Liquorice, $0.5 \mathrm{~g}$ MTB-100 and $2 \mathrm{~g}$ Gromin plus / $\mathrm{kg}$ diet. Aflatoxin B1 was produced through pellets fermentation (22). The estimated amount of oil was gradually added (few drops gradually) and mixing operation was continued for 20 minutes. After homogenous mixture was obtained, certain amount of water was slowly added to the mixture before pressing processes according to Shimeino et al. (23).

\section{Experimental dietary additives}

Aflatoxin B1 (150ppb) was produced by growing Aspergillus Parasiticus (standard toxigenic strain, NRRL 2999 culture, Lyophilized strain, was kindly obtained from Vet. Med. Microbiology Dept., Iowa State University, USA) on Barley Fermentation. The moldy Barley was steamed to kill the fungus, dried, milled and analyzed for aflatoxin determination (24). Medicinal plants (Liquorice ) was gifted from the local market. Chemicals (MTB-100) International free trade from-USE, GUARANTEED ANALYSIS: Glucan Min. 14\%, INGREDIENTS: Inner cell wall extract derived from dried brewer's yeast, Dried fermented corn, Dried Saccharomyces cerevisiae fermentation solubles and Silicon dioxide. Chemicals (Gromin-plus) produced by Varsha Multitech- India. Each $1 \mathrm{Kg}$ contains: Breweries dried yeast (saccharomyces cervicea) $2.5 \times 10^{9} \mathrm{CFU}$, Manan oligosacchhrides 200 gram, Hydrated sodium calcium aluminosilicate (carrier) up to 1000 gram.

The composition and Chemical analysis of the basal and experimental diets were shown in Table 1.
The required amount of the diet was prepared every two weeks and stored in a refrigerator until the beginning of the experiment. The pellets were dried under room temperature for $48 \mathrm{~h}$ before use. Chemical analysis revealed that no differences were observed among all diets. The diets were approximately isonitrogenous and isoenergetic. The CP content was $30.90 \%$ on DM basis, and the NFE values $51.61 \%$, such level was within the range suggested by NRC (25).

Table 1: composition of the control and the experimental diets $\%$

\begin{tabular}{|c|c|c|c|c|c|}
\hline Ingredients & T1 & $\mathrm{T} 2$ & T3 & $\mathrm{T} 4$ & T5 \\
\hline Fish meal & 10 & 10 & 10 & 10 & 10 \\
\hline Soybean meal & 39 & 39 & 39 & 39 & 39 \\
\hline Yellow corn & 28 & 28 & 28 & 28 & 28 \\
\hline Wheat bran & 18 & 18 & 18 & 18 & 18 \\
\hline Sunflower oil & 4 & 4 & 4 & 4 & 4 \\
\hline *Vit.\&Min. mixture & 1 & 1 & 1 & 1 & 1 \\
\hline Total & 100 & 100 & 100 & 100 & 100 \\
\hline Aflatoxin B1(ppb) & - & 150 & 150 & 150 & 150 \\
\hline Liquorice (g) & - & - & 0.1 & - & - \\
\hline MTB-100 (g) & - & - & - & 0.2 & - \\
\hline Gromin plus (g) & - & - & - & - & 0.05 \\
\hline \multicolumn{6}{|c|}{ Chemical proximate analysis (\% DM basis). } \\
\hline Dry matter (DM \%) & & & 91.29 & & \\
\hline Crude protein $(\mathrm{CP} \%)$ & & & 30.92 & & \\
\hline Ether extract (EE \%) & & & 6.97 & & \\
\hline Ash \% & & & 6.30 & & \\
\hline Crude fiber (CF \%) & & & 4.20 & & \\
\hline$* *$ NFE $\%$ & & & 51.61 & & \\
\hline \multicolumn{6}{|c|}{ Calculated energy Values: } \\
\hline ***GE (kcal/100g) & & & 458.35 & & \\
\hline$* * * * \mathrm{DE}(\mathrm{kcal} / \mathrm{g})$ & & & 320.55 & & \\
\hline$* * * * * \mathrm{P} / \mathrm{Er}(\mathrm{g} / \mathrm{kcal})$ & & & 67.45 & & \\
\hline
\end{tabular}

*Vitamins and minerals mixture (product of Victoir) each $3 \mathrm{~kg}$ contain: $12.00 .000 \mathrm{IU}$ Vit. A; 3.00.000 IU Vit. D3; 700 mg Vit. E; 500 mg Vit. K3; 500mg Vit.B1; 200 mg Vit. B2; $600 \mathrm{mg}$ Vit. B6; $3000 \mathrm{mg}$ Vit. B12; $450 \mathrm{mg}$ Vit.C; $3000 \mathrm{mg}$ Niacin; $3000 \mathrm{mg}$ Methionine; $10000 \mathrm{mg}$ Choline Chloride; $600 \mathrm{mg}$ Biotin; $300 \mathrm{mg}$ Folic acid; $670 \mathrm{mg}$ Pantothenic acid; 3000 mg Magnesium Sulphat; $1800 \mathrm{mg}$ Zinc Solphat; $10000 \mathrm{mg}$ Iron Solphat; $3000 \mathrm{mg}$ Copper Solphat; 300mg Cobalt Sulphate. ** NFE (Nitrogen free extract) calculated by differences $[\mathrm{NFE}=100-(\mathrm{CP}+\mathrm{EE}+\mathrm{CF}+\mathrm{Ash})]$. *** Gross energy was calculated according to NRC (25) by using factors of 5.65, 9.45 and $4.22 \mathrm{Kcal}$ per gram of protein, EE and NFE, respectively. ${ }^{* * * *}$ DE (Digestible energy) (Kcal/ $100 \mathrm{~g}$ ), based on $5.0 \mathrm{Kcal} / \mathrm{g}$ protein 9.0 $\mathrm{Kcal} / \mathrm{g}$ EE, $2.0 \mathrm{Kcal} / \mathrm{g}$ NFE According to Wee and Shu (26). $* * * * * \mathrm{P} / \mathrm{Er}$ (protein energy ratio) $=$ crude protein $\mathrm{x}$ $1000 /$ Gross energy. 


\section{Proximate analysis of the experimental diets and fish body}

Proximate analysis for the basal diets and fish body at the start and the end of the experiment for different groups were carried out according to the method described by AOAC (27).

At the end of the experiment, fish samples were derived from each group for drying at $60^{\circ} \mathrm{C}$ for 48 hours and then milled through electrical mill and stored in deep freezer until analysis.

\section{Growth performance and efficiency of feed and protein utilization}

The growth performance and feed utilization parameters were calculated according to the following equations as described by De Silva (28): a-Average weight gain (AWG): $=$ final weight $(\mathrm{g})$ - initial weight $(\mathrm{g})$. b-Average daily gain $(\mathrm{ADG}):=\mathrm{AWG}(\mathrm{g}) /$ Time (days). c-Specific growth rate $(\mathrm{SGR}):=100 \times[$ In final weight $(\mathrm{g})-$ In initial weight $(\mathrm{g}) /$ Experimental period (d) ] (day). d-Survival rate (SR): SR $(\%)=100 \times[$ Total number of fish at the end of the experimental/ Total number of fish at the start of the experimental]. e-Feed conversion ratio (FCR): $F C R=$ Feed Intake (g) /Weight gain (g). f-Protein efficiency ratio (PER): PER =live weight gain (g) / protein intake (g). gProductive protein value (PPV): PPV $(\%)=100 \times[$ Retained $\operatorname{protein}(\mathrm{g}) /$ protein intake $(\mathrm{g})]$.

\section{Blood parameters determination}

At the end of the experimental period, blood samples from the different groups were taken from the caudal vein for serological analysis. Adequate amounts of whole blood were taken in small plastic vials containing heparin.

\section{Hematological parameters}

The blood were diluted with appropriate diluting fluids for $\mathrm{RBC}$ and $\mathrm{WBC}$ counts and were determined using improved Neubauwr haemocytometer and calculated (3). Hemoglobin Concentration ( $\mathrm{Hb} \mathrm{mg} / \mathrm{dl}$ ) was estimated according to the method of Zinkl (29). by using commercial kit (Diamond Diagnostic, Egypt). Packed Cell Volume (PCV \%) was estimated by the microhaematocrite (30).

\section{Biochemical parameters}

Total proteins (TP) were measured using reagent kits obtained from Diamond Diagnostic Company, Egypt (5). Albumin was further assessed electrophoretically in serum (31). Globulin was calculated by mathematical subtraction of albumin value from total proteins (31). Albumin /Globulin $(\mathrm{A} / \mathrm{G})$ ratio was calculated according to the equation described by Zhou et al. (32). Alanine Amino transferees (ALT) and Aspirate Amino transferees (AST) activities were assayed (33) using reagent kits purchased from Randox Company (UK).

\section{Internal organs indices}

All fish were killed at the end of the experiment, and soon the abdominal cavity was opened to remove (liver, Kidney, Gonads and Spleen) which were weighed individually. Hepatic somatic index (HIS), kidney somatic index (KSI), gonads somatic index (GSI), and spleen somatic index (SSI) were calculated as follow: HSI= Liver weight $\times 100$ / fish weight (34). KSI $=$ kidney weight $\times 100$ / fish weight (35). GSI $=$ gonads weight $\times 100$ / fish weight (36). SSI $=$ spleen weight $\times 100 /$ fish weight (34).

\section{Residues of aflatoxin in fish body}

$\mathrm{AFB}_{1}$ residues was extracted and analyzed by the method of Jantrarotai et al. (34) using HPLC. analyzed by the method of using Fluorometer (VICAM), series-4EX.

\section{Statistical analysis}

The data collected were analyzed using statistical package social science procedure by SPSS (2006) for users guide; Means were statistically compared for the significance $(P \leq 0.05)$, using Duncan multiple rang test (37).

\section{Results and discussion}

\section{Growth performance and survival rate}

Data presented in Table 2 showed that aflatoxin B1 (AFB1) had negative effects $(\mathrm{P} \leq 0.05)$ on fish growth performance. Even though, there were no significant $(\mathrm{P} \geq 0.05)$ differences in the initial body weights among all treatments. Average weight gain (AWG), average daily gain (ADG) and specific growth rate (SGR) and survival rate (SR) of the experimental fish were the best for the fish fed T1 (control). However, the addition of all antitoxin additives improved all growth performance parameters compared to T2 (contaminated with aflatoxin B1 $150 \mathrm{ppb}$ ) which was the lowest values for AWG, ADG, SGR and SR. On the other hand, there were no significant differences among fish fed diets $\mathrm{T} 4$ and control while significant differences were found between $\mathrm{T} 4$ and $\mathrm{T} 5 . \mathrm{AFB}_{1}$ at levels of $100 \mathrm{ppb}$ and $150 \mathrm{ppb}$ in the diet of fish fingerlings without adding antitoxins caused a significant growth depression (38). This poor growth might be a result of expelling the feed from the mouth of fish (39).

Also, the same results were reported by Salem et al. (40), who found a significant reduction in growth performance and survival rate of $O$. niloticus fish as affected by aflatoxin $\mathrm{B}_{1}$ (AFB1) in the diet. On the other hand, adding some medicinal plants and some spices to the contaminated diet reduced the toxic effect of the AFB1 and 
stimulated growth performance of the fish and shrimp $(41,42)$.

These results also agreed with the findings reported by Salem et al. (43) and Salem (44) who found that AFB1 at levels of $100 \mathrm{ppb}$ and $150 \mathrm{ppb}$ significantly increased the mortality rate in tilapia. The ability of Rotamin and Power Top to decrease the mortality rate may be due to its constituents that stimulate the immune system (45). Additionally, Zaki et al. (46) mentioned that Aflatoxicosis produce a significant decrease in body weight if compared with the control group. With decreased weight gain and lower feed efficiency, 3 ppm AFB1-exposed fish performed poorly compared to $1.5 \mathrm{ppm}$ AFB1-exposed fish and the control. Reduction in the weight gain and decreases in feed efficiency at the higher dose confirmed the anti-nutritional effects of AFB1 recorded by Zychowski et al. (47).

\section{Feed intake and protein utilization}

All criteria studied which presented in Table 3 showed that $\mathrm{T} 1, \mathrm{~T} 4$ and $\mathrm{T} 3$ were better $(\mathrm{P} \leq 0.05)$ in comparison with the T2 group (containing AFB1) concerning FI, FCR, PER, and PPV\% in tilapia fish. On the other side, there was no significant differences between $\mathrm{T} 1$ and $\mathrm{T} 4$ in the values of FCR, PER, and PPV\%. The addition of MTB-100 was more effective compared to the other treatments. While, the addition of AFB1 (T2) had a negative effect on feed and protein utilization parameters (FI, FCR, PER, and PPV\%). Liquorice and coriandrum stimulates digestion and influences positively the terminal enzymes of the digestive processes $(43,48,49)$.

The present results agreed with the findings (39), who reported a clear reduction in feed consumption in a direct relation to the dietary AFB1 level for $O$. niloticus. Those authors added that the high levels of aflatoxin B1 (10 and $100 \mathrm{mg} \mathrm{AFB} 1 / \mathrm{kg}$ ) led to decrease feed intake. On the other hand, Svobodova et al. (50) concluded that AFB1 at doses of 20 to $200 \mathrm{mg} / \mathrm{Kg}$ of feed did not show any effects on feed and protein utilization. Garlic supplemented diets have immune -stimulation for tilapia (O. niloticus) and improved feed intake, body weight and body weight gain than the groups fed diet with aflatoxin (35).

\section{Internal organ indices}

Significant $(\mathrm{P} \leq 0.05)$ differences were found among the dietary treatments for kidney- somatic index (KSI), hepato -somatic index (HSI), gonads- somatic index (GSI) and spleen-somatic index (SSI) as presented in Table 4.

Generally, from the results in the present study, treatment (T2) caused negative effects on the internal organs indices comparing with the control diet (T1) and the other treatments (T3,T4 and T5). This means that AFB1 not only reduced growth performance of the tested fish, but also negatively altered internal organs function as a consequence of affecting their relative weights, which may be due to changing in their cells number or volume or elevating their water and / or blood contents $(31,51)$.

Hepato - somatic index (HSI) was increased by increasing AFB1 level in the diet of $O$. niloticus but gonado - somatic index (GSI) decreased (52). The aflatoxic diet at a level of $100 \mathrm{ppb}$ AFB1 led to significant increases $(\mathrm{P} \leq 0.05)$ in all organs indices comparing with the control diet (zero ppb AFB1) $(40,44,53)$. However, Zychowski et al. (47), HSI was decreased significantly in groups exposed to AFB1 (54).

Table 2: Growth performance parameters and survival rates of tilapia as affected by the dietary treatments (Mean*+ SE)

\begin{tabular}{ccccccc}
\hline Treatments & $\begin{array}{c}\text { Initial Weight } \\
(\mathrm{g} / \text { fish })\end{array}$ & $\begin{array}{c}\text { Final Weight } \\
(\mathrm{g} / \text { fish })\end{array}$ & $\begin{array}{c}\text { AWG } \\
(\mathrm{g} / \text { fish })\end{array}$ & $\begin{array}{c}\text { ADG } \\
(\mathrm{g} / \text { fish/day })\end{array}$ & $\begin{array}{c}\text { SGR } \\
(\% / \text { day })\end{array}$ & $\begin{array}{c}\text { SR } \\
(\%)\end{array}$ \\
\hline T1 & $13.50 \pm 0.00^{\mathrm{a}}$ & $80.40 \pm 2.40^{\mathrm{a}}$ & $66.90 \pm 2.40^{\mathrm{a}}$ & $0.59 \pm 0.02^{\mathrm{a}}$ & $1.58 \pm 0.02^{\mathrm{a}}$ & $100.0 \pm 0.00^{\mathrm{a}}$ \\
T2 & $13.35 \pm 0.15^{\mathrm{a}}$ & $63.00 \pm 0.20^{\mathrm{d}}$ & $49.65 \pm 0.35^{\mathrm{d}}$ & $0.44 \pm 0.00^{\mathrm{d}}$ & $1.38 \pm 0.01^{\mathrm{d}}$ & $69.99 \pm 3.33^{\mathrm{d}}$ \\
T3 & $13.45 \pm 0.15^{\mathrm{a}}$ & $73.30 \pm 0.30^{\mathrm{bc}}$ & $59.85 \pm 0.45^{\mathrm{bc}}$ & $0.53 \pm 0.00^{\mathrm{bc}}$ & $1.51 \pm 0.01^{\mathrm{bc}}$ & $89.99 \pm 3.33^{\mathrm{b}}$ \\
T4 & $13.30 \pm 0.10^{\mathrm{a}}$ & $77.40 \pm 2.60^{\mathrm{ab}}$ & $64.10 \pm 2.50^{\mathrm{ab}}$ & $0.57 \pm 0.02^{\mathrm{ab}}$ & $1.56 \pm 0.02^{\mathrm{ab}}$ & $96.66 \pm 3.33^{\mathrm{ab}}$ \\
T5 & $13.40 \pm 0.00^{\mathrm{a}}$ & $68.90 \pm 0.70^{\mathrm{c}}$ & $55.50 \pm 0.70^{\mathrm{c}}$ & $0.49 \pm 0.01^{\mathrm{c}}$ & $1.46 \pm 0.01^{\mathrm{c}}$ & $80.00 \pm 0.00^{\mathrm{c}}$ \\
\hline
\end{tabular}

* Means superscripted (in the same column) with different letters significantly $(\mathrm{P} \leq 0.05)$ differ.

Table 3: Feed intake and feed and protein utilization of Nile tilapia as affected by the dietary treatments (Mean*+ SE)

\begin{tabular}{lcccc}
\hline Treatment & Feed Intake $(\mathrm{g})$ & FCR $(\mathrm{g})$ & PER $(\mathrm{g})$ & PPV $(\%)$ \\
\hline T1 & $101.02 \pm 3.07^{\mathrm{b}}$ & $1.51 \pm 0.10^{\mathrm{d}}$ & $2.14 \pm 0.14^{\mathrm{a}}$ & $33.65 \pm 0.03^{\mathrm{a}}$ \\
T2 & $124.95 \pm 2.55^{\mathrm{a}}$ & $2.51 \pm 0.03^{\mathrm{a}}$ & $1.28 \pm 0.02^{\mathrm{d}}$ & $19.84 \pm 0.82^{\mathrm{c}}$ \\
T3 & $108.82 \pm 4.12^{\mathrm{b}}$ & $1.81 \pm 0.08^{\mathrm{c}}$ & $1.78 \pm 0.08^{\mathrm{bc}}$ & $28.88 \pm 2.37^{\mathrm{b}}$ \\
T4 & $104.10 \pm 0.45$ & $1.62 \pm 0.07^{\mathrm{dd}}$ & $1.98 \pm 0.08^{\mathrm{ab}}$ & $31.07 \pm 0.38^{\mathrm{ab}}$ \\
T5 & $11842 \pm 1.12^{\mathrm{a}}$ & $2.13 \pm 0.05^{\mathrm{b}}$ & $1.51 \pm 0.03^{\mathrm{cd}}$ & $23.16 \pm 0.72^{\mathrm{c}}$ \\
\hline
\end{tabular}

$\mathrm{a}, \mathrm{b}, \mathrm{c}, \mathrm{d}$ and e means in the same column bearing different letters differ significantly at 0.05 level. 
On the other hand, the additives (tafla, ammonia and hydrogen peroxide) did not alter the organs weights; yet, they slightly diminished -to some extent - the negative effect of dietary aflatoxin inclusion on the relative weights of all tested organs (53). Also, Shehab El-din et al. (15) found that the additives of $0.2 \%$ Rotamin and $0.3 \%$ Power top as antimycotoxins for Nile tilapia rations caused a decrease in hepato -somatic indices comparing with the aflatoxin B1 contaminated diet. In the present study, the effects of chemicals (MTB-100) and medicinal plants (Liquorice) additives may be due to the increase of fish immunity, reduced the effect of the toxin of AFB1 and hence hide its negative effects on indices of fish. Additionally, the HSI was decreased significantly in groups exposed to AFB1 (47,54-56).

\section{Proximate chemical analysis of the whole fish body}

The proximate chemical analysis of the whole body of the tested tilapia fish is given in Table 5. The control, T4 and $\mathrm{T} 5$ diets had the highest DM content compared with the other treatments, while the fish fed T2 had the lowest DM content. There were significant differences among the dietary treatments for $\mathrm{CP}$ contents. The highest $\mathrm{CP}$ was observed in the fish groups fed T1 (control), T4 and T3 and the lowest values were in groups $\mathrm{T} 2$, and $\mathrm{T} 5$. The differences were significant $(\mathrm{P} \leq 0.05)$ for $\mathrm{EE}$ and ash among all treatments. Generally, the addition of MTB-100 and Liquorice improved proximate analysis of fish carcass.

Similar results were reported by Salem (49), who concluded that the percentages of DM and CP decreased as the levels of the aflatoxin B1 increased, while the values of EE and ash increased with increasing the levels of AFB1. Additionally, aflatoxin B1 significantly reduced DM and CP content of the $O$. niloticus fish carcass, but it significantly increased EE and ash content of the fish $(53,57,58)$. Also, Salem (44) found high significant $(\mathrm{P} \leq 0.05)$ differences among the dietary treatments in $\mathrm{CP}$, $\mathrm{EE}$ and ash contents. The highest $\mathrm{CP}$ was observed in the fish groups of T1, T3, T4 and T5 and the lowest values were found in groups T2. The highest EE was observed in the fish group of $\mathrm{T} 2$.

\section{Residues of aflatoxin in the whole fish body}

Data concerning aflatoxin (AFB1) residues in the whole fish body in the different experimental groups are shown in Table 6. The group fed AFB1 contaminated diet (150 ppb) T2 without any feed additives, showed the highest level (12.0 ppb aflatoxin B1) in fish body, followed by the group fed AFB1 contaminated with Liquorice, MTB-100 and Gromin plus which were 3, 3 and 8 ppb for T3, T4, and T5, respectively, So, T3 and T4 was the best treatments in reducing these residues.

Table 4: Internal organs indices of the tilapia fish at the end of experimental period as affected by the experimental diets (Means $* \pm \mathrm{SE})$

\begin{tabular}{lccccc}
\hline \multirow{2}{*}{ Treatment } & \multirow{2}{*}{ HSI (\%) } & \multirow{2}{*}{ KSI (\%) } & \multicolumn{2}{c}{ GSI (\%) } & \multirow{2}{*}{ SSI (\%) } \\
\cline { 4 - 5 } & & & Females & Males & \\
\hline T1 & $3.44 \pm 0.11^{\mathrm{b}}$ & $0.47 \pm 0.00^{\mathrm{d}}$ & $1.73 \pm 0.20^{\mathrm{a}}$ & $0.88 \pm 0.05^{\mathrm{a}}$ & $0.30 \pm 0.01^{\mathrm{d}}$ \\
\hline T2 & $5.08 \pm 0.18^{\mathrm{a}}$ & $2.04 \pm 0.05^{\mathrm{a}}$ & $0.98 \pm 0.13^{\mathrm{b}}$ & $0.25 \pm 0.10^{\mathrm{d}}$ & $0.68 \pm 0.00^{\mathrm{a}}$ \\
T3 & $3.85 \pm 0.28^{\mathrm{b}}$ & $0.72 \pm 0.06^{\mathrm{c}}$ & $1.51 \pm 0.23^{\mathrm{ab}}$ & $0.77 \pm 0.07^{\mathrm{ab}}$ & $0.38 \pm 0.00^{\mathrm{c}}$ \\
T5 & $3.93 \pm 0.20^{\mathrm{b}}$ & $0.66 \pm 0.01^{\mathrm{c}}$ & $1.56 \pm 0.08^{\mathrm{ab}}$ & $0.45 \pm 0.05^{\mathrm{cd}}$ & $0.40 \pm 0.01^{\mathrm{c}}$ \\
T5 & $4.82 \pm 0.05^{\mathrm{a}}$ & $1.60 \pm 0.07^{\mathrm{d}}$ & $1.16 \pm 0.19^{\mathrm{ab}}$ & $0.58 \pm 0.03^{\mathrm{bc}}$ & $0.51 \pm 0.00^{\mathrm{b}}$ \\
\hline
\end{tabular}

* Means superscripted (in the same column) with different letters significantly $(\mathrm{P} \leq 0.05)$ differ.

Table 5: Proximate chemical analysis (\% DM basis) and energetic value of the whole tilapia body as affected by the experimental diets (Mean*+ SE)

\begin{tabular}{lcccc}
\hline \multirow{2}{*}{ Treatment } & \multicolumn{4}{c}{$\%$ On Dry matter basis } \\
\cline { 2 - 5 } & DM $\%$ & CP \% & EE \% & Ash \% \\
\hline At the start of the experiment & \multicolumn{5}{c}{16.89} \\
\hline Initial & 26.45 & 65.58 & 17.51 & \\
\hline At the end & & & & \\
T1 & $27.54 \pm 0.13^{\mathrm{a}}$ & $65.81 \pm 0.31^{\mathrm{a}}$ & $16.56 \pm 0.47^{\mathrm{c}}$ & $17.21 \pm 0.25^{\mathrm{a}}$ \\
T2 & $26.39 \pm 0.02^{\mathrm{a}}$ & $62.96 \pm 0.16^{\mathrm{b}}$ & $19.68 \pm 0.05^{\mathrm{a}}$ & $17.35 \pm 0.11^{\mathrm{a}}$ \\
T3 & $26.85 \pm 0.05^{\mathrm{a}}$ & $64.99 \pm 0.43^{\mathrm{a}}$ & $17.20 \pm 0.20^{\mathrm{bc}}$ & $17.34 \pm 1.07^{\mathrm{a}}$ \\
T4 & $27.00 \pm 0.95^{\mathrm{a}}$ & $65.30 \pm 0.08^{\mathrm{a}}$ & $16.93 \pm 0.09^{\mathrm{c}}$ & $17.77 \pm 0.17^{\mathrm{a}}$ \\
T5 & $27.35 \pm 0.81^{\mathrm{a}}$ & $63.78 \pm 0.34^{\mathrm{b}}$ & $18.24 \pm 0.38^{\mathrm{b}}$ & $17.82 \pm 0.02 \mathrm{a}$ \\
\hline
\end{tabular}

* Means superscripted (in the same column) with different letters significantly $(\mathrm{P} \leq 0.05)$ differ. 
In this respect, AFB1 residues in the O. niloticus flesh showed a cumulative effect related to the levels of dietary AFB1 and feeding period (57). Also, Soliman et al. (59) found that the significant increase of aflatoxin residues was observed in $O$. niloticus fish after 6 months. Residues of AFB1 in the whole body of $O$. niloticus at the end of the experiment tended to decrease after a freezing period $(40,44,57)$.

Table 6: The residues of aflatoxin B1 in the tilapia fish (wet weight basis) as affected by the dietary treatments (Means)

\begin{tabular}{lccccc}
\hline Treatment & T1 & T2 & T3 & T4 & T5 \\
\hline $\begin{array}{l}\text { AFB1 in whole } \\
\text { Body fish (ppb) }\end{array}$ & Zero & 12 & 3 & 3 & 8 \\
\hline
\end{tabular}

\section{Blood analysis}

Serum total protein, albumin and globulin concentrations were significantly lower in $O$. niloicus fed on AFB1 containing rations comparing with the control, but addition of antimycotoxins the serum protein level, albumin and globulin were improved (Table 7).

Nearly similar results were recorded in O. niloticus $(27,60)$. Several authors also reported a reduction in plasma protein concentration in fresh water fish $(O$. niloticus and rainbow trout) exposed to mycotoxins $(16,61)$. Additionally, a decrease in total plasma protein and albumin blood levels was reported in Labeo rohita exposed to AFB1 (62). Selim et al. (43) observed a decrease in plasma protein and globulin in Oreochromis niloticus fed aflatoxin B1 containing ration. Moreover, aflatoxin hepatotoxicity leads to alterations in protein synthesis and cellular integrity of the liver (63). Serum globulin reduction may be related to hemopoietic toxicity (anterior kidney and spleen) and lymphocytolysis (64). Aflatoxin B1 also proved to be immunosuppressive in fish (62).

The activities of ALT and AST were significantly $(\mathrm{P} \leq 0.05)$ elevated in the serum of $O$. niloicus fed ration containing aflatoxin B1 comparing with the control one. The results indicated that the antimycotoxins improved the enzymes ALT and AST activities against aflatoxins through lowering ALT and AST activities levels than that of AFB1 treated group but still higher than that in the control group (Table 8).

The present results were in similar to results in $O$. niloicus and lates niloticus, respectively $(60,65)$. Pepeljnjak et al. (61) reported elevation in liver transaminase enzymes in Cyprinus carpio fed $5.0 \mathrm{mg}$ AFB $1 / \mathrm{kg}$ body weight for 42 days. Also, an elevation was observed in liver transaminase of $O$. niloticus that had been intoxicated with AFB1 (52). Nearly similar results were obtained (66), who observed an increase in serum transaminase and alkaline phosphatase activities in sea bass exposed to prolonged oral administration of aflatoxins. Also, Selim et al. (67) recorded increases in serum AST and ALT in O. niloticus fed aflatoxin B1 containing ration. However, the exposure of gibel carp fish to aflatoxin B1 in the diet had no significant effect on serum AST and ALT enzymes activities (68).

Saad et al. (69) stated that the groups treated with black seed, garlic and onion had a higher total protein, albumin, globulin and albumin globulin ratio than the other treated groups. Also, aflatoxin causes a decrease in the serum protein level but by the addition of natural feeds as black seed, garlic and onion which improved the serum protein level.

The results showed a significant decrease in RBCs counts, $\mathrm{Hb}$ concentration and Packed cell volume (PCV) (normocytic norm-chromic anemia), however increase in WBCs concentration in the blood of $O$. niloticus fed on AFB1 containing ration were recorded as compared with the control group (Table 8).

The results indicated that the antimycotoxins improved the fish erythrogram picture against aflatoxins through improving RBCs, Hb, PCV and WBCs level than that of AFB1 treated group (T3) followed by $\mathrm{T} 4$ and T5, respectively but still lower than that of the control group.

The main hemopiotic tissue in O. niloticus is anterior kidney (59). Renal damage of AFB1 treated channel catfish was reported $(70,71)$, as well as in common carp (61). Similarly, anemia in $O$. niloticus exposed to $0.5 \mu \mathrm{g}$ or 1.0 $\mu \mathrm{g}$ AFB1 / Kg B.W. for 10 days (16). Also, anemia noticed in $O$. niloticus and $O$. aureus fed on ration supplemented with aflatoxins (33). Additionally, normocytic normochromic anemia in AFB1 treated group $(15,60,69)$.

The present results concerning AST and ALT activity had widely differences among the different treatment (Table 7) indicating a damage of the liver and probably also the kidney. Moreover, Abdelhamid et al. (53) found that the activity of AST and ALT enzymes increased significantly $(\mathrm{P} \leq 0.05)$ in the fish fed aflatoxin-B1 contaminated died. These finding agreed with evidence for acute aflatoxin-B1 nephrotoxicity which was provided by distended gall bladder indicating disrupted osmoregulation (i.e. water retention ) as reported by Mehrim et al. (58).

Recently In the same trend, Abdelhamid et al. (53) and Mehrim et al. (58) found that AFB1 caused not significant decrease in concentration of red blood cells count and significantly increase in white blood cells count and transaminases activity of aflatoxicated $O$. niloticus fish. As well as, the positive effects of some nutritional additives used in the present study, namely MTB-100, Liquorice and Gromin-plus may be due to the increased of immunity and hence hide its negative effects on blood parameters of $O$. niloticus fish. 
Table 7: Effect of dietary supplementation with AFB1 and anti-mycotoxin on some plasma biochemical parameters (Mean* \pm S.E) in Nile tilapia (Oreochromis. niloticus) fed the different experimental diets

\begin{tabular}{lcccccc}
\hline Treatment & $\begin{array}{c}\text { Total protein } \\
(\mathrm{g} / 100 \mathrm{ml})\end{array}$ & $\begin{array}{c}\text { Albumin } \\
(\mathrm{g} / 100 \mathrm{ml})\end{array}$ & $\begin{array}{c}\text { Globulin } \\
(\mathrm{g} / 100 \mathrm{ml})\end{array}$ & $\begin{array}{c}\text { A/G ratio } \\
(\mathrm{g} / 100 \mathrm{ml})\end{array}$ & $\begin{array}{c}\text { ALT } \\
(\mathrm{m} / \mathrm{l})\end{array}$ & $\begin{array}{c}\text { AST } \\
(\mathrm{m} / \mathrm{l})\end{array}$ \\
\hline $\mathrm{T} 1$ & $6.93 \pm 0.27^{\mathrm{a}}$ & $3.75 \pm 0.05^{\mathrm{a}}$ & $3.18 \pm 0.28^{\mathrm{a}}$ & $0.84 \pm 0.04^{\mathrm{a}}$ & $7.14 \pm 0.31^{\mathrm{c}}$ & $89.50 \pm 0.50^{\mathrm{a}}$ \\
$\mathrm{T} 2$ & $5.07 \pm 0.03^{\mathrm{c}}$ & $3.15 \pm 0.05^{\mathrm{c}}$ & $1.92 \pm 0.09^{\mathrm{b}}$ & $0.60 \pm 0.03^{\mathrm{a}}$ & $13.05 \pm 0.21^{\mathrm{a}}$ & $117.69 \pm 5.64^{\mathrm{a}}$ \\
$\mathrm{T} 3$ & $6.12 \pm 0.22^{\mathrm{ab}}$ & $3.60 \pm 0.05^{\mathrm{ab}}$ & $2.51 \pm 0.27^{\mathrm{b}}$ & $0.69 \pm 0.08^{\mathrm{a}}$ & $12.86 \pm 0.53^{\mathrm{a}}$ & $104.84 \pm 5.54^{\mathrm{a}}$ \\
$\mathrm{T} 4$ & $5.97 \pm 0.22^{\mathrm{bc}}$ & $3.58 \pm 0.01^{\mathrm{b}}$ & $2.39 \pm 0.23^{\mathrm{b}}$ & $0.66 \pm 0.06^{\mathrm{a}}$ & $8.71 \pm 1.16^{\mathrm{bc}}$ & $96.09 \pm 5.21^{\mathrm{a}}$ \\
$\mathrm{T} 5$ & $5.65 \pm 0.35^{\mathrm{bc}}$ & $3.49 \pm 0.04^{\mathrm{b}}$ & $2.16 \pm 0.31^{\mathrm{b}}$ & $0.61 \pm 0.08^{\mathrm{a}}$ & $11.84 \pm 1.60^{\mathrm{ab}}$ & $93.45 \pm 4.88^{\mathrm{a}}$ \\
\hline
\end{tabular}

Table 8: Effect of dietary supplementation with AFB1 and Anti-mycotoxin on erythrogram picture (Mean* \pm S.E) in Nile tilapia (Oreochromis niloticus) fed the different experimental diets

\begin{tabular}{lcccc}
\hline Treatment & $\mathrm{RBC}\left(\times 10^{3} / \mathrm{mm}^{3}\right)$ & $\mathrm{Hb}(\mathrm{g} / 100 \mathrm{ml})$ & $\mathrm{PCV}(\%)$ & $\mathrm{WBCs}\left(\times 10^{3} / \mathrm{mm}^{3}\right)$ \\
\hline T1 & $2.35 \pm 0.04^{\mathrm{a}}$ & $6.94 \pm 0.06^{\mathrm{a}}$ & $20.50 \pm 0.50^{\mathrm{a}}$ & $53.98 \pm 3.65^{\mathrm{c}}$ \\
T2 & $1.19 \pm 0.09^{\mathrm{c}}$ & $3.95 \pm 0.06^{\mathrm{d}}$ & $14.50 \pm 0.50^{\mathrm{c}}$ & $68.01 \pm 1.01^{\mathrm{a}}$ \\
T3 & $2.18 \pm 0.21^{\mathrm{a}}$ & $5.06 \pm 0.05^{\mathrm{c}}$ & $17.50 \pm 1.50^{\mathrm{abc}}$ & $59.00 \pm 0.30^{\mathrm{bc}}$ \\
T4 & $2.04 \pm 0.16^{\mathrm{ab}}$ & $6.10 \pm 0.20^{\mathrm{b}}$ & $19.50 \pm 1.50^{\mathrm{ab}}$ & $58.51 \pm 0.62^{\mathrm{bc}}$ \\
T5 & $1.69 \pm 0.01^{\mathrm{b}}$ & $4.98 \pm 0.04^{\mathrm{c}}$ & $16.50 \pm 0.50^{\mathrm{bc}}$ & $61.27 \pm 0.71^{\mathrm{b}}$ \\
\hline
\end{tabular}

\section{Conclusion}

From the foregoing results it could be concluded that aflatoxin contaminated diets caused many drastic effects in all tested parameters. Adding MTB-100 (chemicals) and Liquorice (medicinal plants) at level (1gm and $2 \mathrm{gm} / \mathrm{kg}$ feed) to the diets of Nile tilapia showed positive effects on all fish performance parameters as well as alleviate the toxic effects of AFB1 contaminated diets. Moreover, it is needed a lot of scientific efforts in this trend to detoxify mycotoxin (particularly aflatoxin) in diets of fish.

\section{Acknowledgments}

Great thanks to all members of Central Laboratory for Aquaculture Research, Abbassa, Sharkia, Sakha Aquaculture Research Unit and Animal Production Department, Faculty of Agriculture, Kafrelsheikh University.

\section{References}

1. Fowler J, Hashim M, Velazquez ALB, Deng Y, Bailey CA. Utilization of a spray-applied calcium bentonite clay to ameliorate the effects of low-levels of aflatoxinin starter broiler diets containing DDGS. Nat. Prod Chem Res. 2014;2:127-130.

2. Atroshi FA, Rizzo I, Biese M, Salonen LA, Lindberg H, Saloniemi.. Effects of feeding T-2 toxin and deoxynivalenol on DNA and GSH contents of brain and spleen of rats supplemented with vitamin $\mathrm{E}$ and C and selenium combination. J Anim Phys Nutr. 1995;74:157-164.

3. Baudrimont I, Ahouandjivo R, Creppy. E. E. Prevention of lipid peroxidation induced by ochratoxin A in vero cells in culture by several agents. Chem Biol Interact. 1997;104:29-40.
4. Creppy EE, Baudrimont I, Betbeder AM. How as partame prevents the toxicity of ochratoxin A. J Toxical Sci.1998;2:165-172.

5. Henry RJ. Colorimetric determination of total protein. In: Clinical Chemistry. Harper and Row Publ., New York, USA. 1964.

6. Hoehler D, Marquardt RR. Influence of vitamins $\mathrm{E}$ and $\mathrm{C}$ on the toxic effects of ochratoxin A and T-2 toxin in chicks. Poult Sci. 1996;75:1508-1515.

7. Bata A, Lasztity R. Detoxification of mycotoxin- contaminated food and feed by microorganissms. Trends Food Sci Technol. 1999;10:223228.

8. Conner DE. Naturally occurring compounds. In: Davidson, PL. Branem, A L. (Eds.), Antimicrobials in Foods. Marcel Dekker, New York, 1993; pp: 441-468.

9. FAO, Food and Agriculture Organization of the United Nation. Evaluation of Certain Mycotoxins in Food: Fifty - sixth Report of the Joint FAO / WHO Expert Committee on food Additives, World Health Organization, Geneva. 2002.

10. Oliveira CAF, Bovo F, Corassin CH, Jager AV, Reddy KR. Recent trends in microbiological decontamination of aflatoxins in foodstuffs. In: Razzaghi-Abyaneh, M. Eds., Aflatoxins, Recent Advances and Future Prospects. Publisher InTech, Croatia. 2013; 59-92.

11. Sahoo PK, Mukheriee SC. Immunomodulation by dietary vitamin C in healthy and aflatoxin B1 - induced immunocompromised Indian major carp Labeo rohita. Compara Immunol Microbiol Infect Dis. $2003 ; 26: 12-65$.

12. Zaky ZM, Sharkawy AA, Mubarak M, Ahmed AI. Effect of some immunstimulants on aflatoxicosis in ducks. Proc. Conf. Mycot Dioxins Environ Bydgoszcz. 25-27 Sep. 2000; pp: 93 - 104.

13. CAST. Mycotoxins risks in plant, animal and human systems Council for Agricultural Science and Technology Task Force Report No. 139, Ames, Iowa, USA, 2003; ISBN $1-887383-22-0.2742$.

14. Nayek SK, Swain P, Mukherjee SC. Effect of dietary supplementation of probiotic and vitamin $\mathrm{C}$ on the immune response of Indian major carp, Labeo rohta (Ham.). Fish \& Shellfish Immunol. 2007;23 (4):89 -896 .

15. Shehab El-din MT, Guda AH, Salem MFI, El-komy HM. Studies on some prebiotics as antimycotoxins for Nile tilapia rations. J Agric Res Kafr El-Sheikh Univ. 2013;39 (1):13-20.

16. Hussain D, Mateen A, Gatlin DM. Alleviation of aflatoxin B 1 (AFB 1) toxicity by calcium bentonite clay: Effects on growth performance, 
condition indices and bioaccumulation of AFB 1 residues in Nile tilapia (Oreochromis niloticus). Aquacul. 2017

17. Tsadik GG, Bart AN. Effects of feeding, stocking density and waterflow rate on fecundity, spawning frequency and egg quality of Nile tilapia, Oreochromis niloticus (L.). Aquacul. 2007;272:380-388.

18. GAFRD (The General Authority For Fish Resources Development. Fish statistics year book. 2016.PP:13-14.

19. El-Husseiny OM, Goda AM, Abdul-Aziz GM, El-Haroun ER. Fishmeal free diets for Nile Tilapia Oreochromis niloticus (L.), Mugill cephalous and Liza ramada in Semi-intensive polyculture system in earthen ponds. Egypt J. Nutrit Feeds. 2007;10(1):179-203.

20. El-Saidy DMS, Gaber M.). Effect of dietary protein levels and feeding rates on growth performance, production traits and body composition of Nile tilapia (Oreochromis niloticus L).cultured in concrete tanks. Aquacul Res. 2005; 36:163-171.

21. El-Sayed AK. Influence of some probiotics supplementation in diets on growth, reproductive performance and biochemical parameters of Japanese quail. A thesis for the Degree of Master in Veterinary Sci. in Nutrition and Nutrition Deficiency diseases. Fac. of Veterinary Med., Alexandria University. 2007.

22. Abdelhamid MA, Mahmoud KI. Elimination or adsorption of aflatoxin from poultry feedstuffs. Proc. Conf. Foodborne Contamination \& Egyptians Health, Mansoura Univ. 1996; pp: 26-27, 61-69.

23. Shimeino S, Masumoto T, Hujita T. Alternative protein sources for fish meal diets of young yellowtail. Nippon Suisan Gakkaishi. 1993;59:137-143.

24. Rank C, Nielsen KF, Larsen TO, Varga J, Samson RA, Frisvad JC. Distribution of sterigmatocystin in filamentous fungi. Fungal biol. 2011; 115(4):406-420.

25. NRC (National Research council). Nutrient requirements of fish and shrimp. National academies press. 2011.

26. Wee KL, Shu, SW. The nutritive value of boiled feel-fat soybean in pelted feed for Nile tilapia. Aquacul. 1989;81:303-314.

27. AOAC. Association of Official Analysis of Chemists, 15th Ed. Washington USA. 1990

28. De Silva SS, Anderson TA. Fish nutrition in aquaculture Ed., Champ man and Hall, 2-6 Bouday Raw, London SE18 FIN, UK. 1995.

29. Zinkl JG. Avian hematology. In: Jain NC (Edd. Schalms Veterinary Hematology, Philadelphia, Paihea and Febiger 1986; pp:256-260.

30. Decie SIV, Lewis SM. Practical Hematology. 10th Edn., Churchill Livingstone, London. ISBN: 2006;13:978-443.

31. Kohin JA. Micro electrophoretic method. Nature. 1958;181:838.

32. Zhou X, Tian Z, Wang Y, Li W. Effect of treatment with probiotics as water additives on tilapia (Oreochromis niloticus) growth performance and immune response. Fish physiol Biochem. 2010;36:501-509.

33. Reitman S, Frankel S. A colourmetric method for the determination of serum glutamic oxaloacetic and glutamic pyruvic transaminases. Amer J Clin Pothole. 1957;28: 56

34. Jangaard PM, Ackman RG, Spios JC. Seasonal studies of the fatty acids composition of cod liver flesh, roe and milt lipids. J Fish Res Bd Canada. 1967;24: 613- 627.

35. Aly RS, Mohamed M. Effect of Nigella sativa on ingestion ability of mice peritoneal macrophages. Saudi Pharma. J.2010; 1:18.

36. Tseng WY, Chan KL. The reproductive biology of the rabbit fish in Hong Kong J. World Maricul., 13:313-321 United Nations. http:// www.fao.org). 1982.

37. Duncan DB. Multiple range and multiple $F$ tests. Biometrics 1955;11(1): 1-42.

38. Abdelhamid MA. Thirty years (1978-2008) of mycotoxin research at faculty of agriculture, AL Mansoura University, Egypt. Engormix.com, Mycotoxins Technical Articles. 2008; pp:11.

39. Nguyen AT, Grizzle JM, Lovell RT, Manning BB, Rottinghaus EG. Growth and hepatic lesions of Nile tilapia Oreochromis niloticus fed diets containing aflatoxin B1. Aquacul. 2002; 212: 311-319.
40. Salem MFI, Abd El-Raouf EM, Eweedah NM, Mohamed BS. Influence of some medicinal plants as antimycotoxins in Nile tilapia (O. niloticus) diets. Proced Conf Fish production. Oct 2009;pp:10-26.

41. El-Dakar AY, Shymaa AY, Shalaby M, Abead SM. Use of as feeding stimulation in diets of marine shrimp Penaeus japonicus. Egypt Ion J. Nutrit feed. 2005;8 (1):106-1076.

42. Russo JAR, Yanong RPE. Molds in fish feeds and aflatoxicosis. University of Florida, IFAS Extension FA95, 2013pp:1-3.

43. Salem MFI, Abd El-Raouf EM, Eweedah NM, Mohamed BS. Influence of some medicinal plants as anti-mycotoxins in Nile tilapia (O. niloticus) diets. Proc. Global Fish Aquacul Res Conf. 24-26 October 2010; pp: 227-242.

44. Salem MFI. An attempt for reduction aflatoxicosis B1 in Nile tilapia (O. niloticus) through medicinal plant. Egypt J. Nutrit Feeds. 2012;15 (1):203-213.

45. Piraret N, Kabayashi T, Katagiri T, Maita M, Endo M. Protective effects. And mechanisms of a probiotic bacterium Lactobacillus Rhamnosus against experimental Edwardsiell tarda infection in Tilapia (O. niloticus). Vet Immunol Immunopathol. 2006;113 (3/4): 339-347.

46. Zaki MS, Fawzi OM, Omar S, Khafagy M, Fawzy M, Awad I. Diminution of aflatoxicosis in Tilapia zilli fish by dietary supplementation with fix in toxin and Nigella sativa oil. Nature Sci. 2010;8 (2):43-49.

47. Zychowski KE, Pohlenz C, Mays T, Romoser A, Hume M, Buentello A, Gatlin III DM, Phillips TD. The effect of Nova Sil dietary supplementation on the growth and health performance of Nile tilapia (Oreochromis niloticus) fed aflatoxin-B1 contaminated feed. Aquacul. 2013;376:117-123.

48. Abdel-Wahab AM, Hassouna MM, Abdel-Maksoud AM, Abu-Seef RAM. Cinnamon as a feed supplement in Nile tilapia, Oreochromis niloticus, diets that reared in earthen ponds. Egyp J Nutrit Feeds. 2007;10 (2): 331-890.

49. Salem MFI. Effect of dietary graded levels of aflatoxin B1 on growth performance and chromosomal behavior of Nile tilapia (O. niloticus) diets. PhD. Thesis. Kafr El-sheikh, Tanta Univ. 2002.

50. Svobodova Z, Piskac A, Havilikova J, Groch L. The influence of feed with different contents of aflatoxin B1 on carp health condition. Zivotisna Vyroba. 1982;27:811-820.

51. Galvano F, Piva A, Ritieni A, Galvano G. Dietary strategies to counteract the effects of myctoxins: a review. J Food Protec. 2001;64:120-131.

52. Hussein SY, Mekkawy IA, Mokhtar ZZ, Mubarak M. Protective effect of Nigella sativa seed against aflatoxicosis in Oreochromis niloticus. Proced Conf Mycotox Dioxins Environ. Bydgoszcz. 2000; pp:109130.

53. Abdelhamid MA, Nemetallah BR, Abd Allah MA, Mousa TAE. Hemalytic activity in blood serum of Oreochromis niloticus under different types of stress. The 3rd Int. Confer for Develop Enviro. Arab World. Assuit Univ. March 2006; pp:21-23, 153-169.

54. El-Barbary I Manal, Mahmoud HM. Chemoprevention and Therapeutic Efficacy of Glutathione Against Aflatoxicosis in Nile Tilapia (Oreochromis niloticus). Global Veterinaria. 2014;13 (6): 1111-1121.

55. Deng SX, Tian LX, Liu FJ, Jin SJ, Liang GY, Yang HJ, Du ZY, Liu YJ. Toxic effects and residue of aflatoxin B1 in tilapia (Oreochromis niloticus $\times$ O. aureus). Aquacul. 2010;307:233-240.

56. Huang Y, Han D, Xiao X, Zhu X, Yang Y, Jin U, Chen Y, Xie S. Effect of dietary aflatoxin B1 on growth, fecundity and tissue accumulation in gibel carp during the stage of gonad development $\mathrm{J}$. Aquacul. 2014; 428-429: 236-242.

57. Abdelhamid MA, Abdel- Khalek AE, Mehrim AL, Khalil FF. An attempt to alleviate aflatoxicosis on Nile tilapia fish by dietary supplementations with chicken-hatchery by-products (egg shells) and shrimp processing wastes (shrimp shells). 2- On clinical, blood and histological parameters. S Agric Sci. Mansoura Univ. 2004;29:61756196. 
58. Mehrim AI, Abdelhamid AM, Abo Shosha AA, Salem MFI, ElSharawy MAMM. Nutritious Attempts to Detoxify Aflatoxic Diets of Tilapia Fish 2- Clinical, Biochemical and Histological Parameters. J Arabian Aquacul. Soc. 2006;1 (2):69- 90.

59. Soliman KM, Ayesh AM, Essa MAM, Naguib K. Fix-A-tox in aquaculture: 1-Effect of aflatoxin decontamination by a selective chemisorbent materials on the Oreochromis niloticus with considering fish processing efficiency. J Egypt Ger Soc Zoot. 25 (a) Compara Physiol.1998;1-19.

60. El-Boshy ME, El-Ashram AMM, Abd El-Ghany A. Nadia. Effect of dietary BETA- 1, 3 Glucan on immunomodulation on diseased (Oreochromis niloticus) experimentally infected with aflatoxin B1. Internat Symp on Tilapia in Aquaculture. 2008;8:1109-1127.

61. Pepeljnjak S, Petrinec Z, Kovacic S, Segvic M. Screening toxicity study in young carp (Cyprinus carpio L.) on feed amended with fumonisin B1. Mycopathologia, 2003;156 (2):139-45.

62. Sahoo PK, Mukherjee SC. Immunosuppressive effects of aflatoxin B1 in Indian major carp (Labeo rohita). Compara Immunol Microbiol Infect Dis. 2001 24:143-149.

63. Jindal IV, Mahipal SK. Toxicity of Aflatoxin B1 in broiler chicks and its reduction by activated charcoal. Res Vet Sci. 1994; 56:37.
64. Sahoo PK, Mukherjee SC, Nayak SK, Dey S. Acute and subchronic toxicity of AFB1 to rohu, Labeo rohita (Hamilton). Indian J Experimen Biol. 2001;39: 453-458.

65. Arafa MM, Ali AT, Mohammed F. Samia. Detecting the effect of Aflatoxin B1 polluted rations on freshwater fish, Lates niloticus reared in fish culture ponds. Current Sci Internat. 2014;3(1)34-39.

66. El-Sayed YS, Khalil RH. Toxicity, biochemical effects and residue of aflatoxin B1 in marine water - reared sea bass (Dicentrachus Labrax L.). Food Chem Toxicol 2009;47:1606-1609.

67. Selim KM, El-hofy H, Khalil RH. The efficacy of three mycotoxin adsorbents to alleviate aflatoxin B1-induced toxicity in Oreochromis niloticus. Aquacult Int. 2014;22:523-540.

68. Hoult JR, Paya M. Pharmacological and biochemical actions of simple coumarins: Natural products with therapeutic potential. Gen Pharmacol. 1996;50: 221-224.

69. Saad TT, Ahmed HA, El-Gohary M, Ali MA. Economic studies on immunostimulents in relation to mycotoxin infection in cultured fish. Online J Anim Feed Res. 2013; 3(1):47-57.

70. Jantrarotai W, Lovell RT. Subchronic toxicity of dietary aflatoxin B1 to channel catfish. J. Aquatic Animal Health. 1990;2:248- 254.

71. Jantrarotai W, Lovell RT, Grizzle JM. Acute toxicity of aflatoxin B1 to channel catfish. J Aquat Anim Health. 1990;2:237-247. 